\title{
MECHANISTIC INVESTIGATION OF OXIDATION OF SOME AMINO ACIDS BY BIS(DIHYDROGEN TELLURATE)ARGENTATE(III) ION IN ALKALINE MEDIUM. A KINETIC STUDY
}

\author{
SHUYING HUO*, CHANGYING SONG, JINHUAN SHAN, SHIGANG SHEN, HANWEN SUN
}

\author{
Key Laboratory of Analytical Science and Technology of Hebei Province, College of Chemistry and Environmental Science,
} Hebei University, Baoding 071002, China

(Received: February 24, 2009 - Accepted: July 1, 2009)

\begin{abstract}
The oxidation of leucine, isoleucine and valine by bis(dihydrogen tellurate)argentate(III) ion was studied by stopped-flow technique. It was both first order with respect to $\mathrm{Ag}(\mathrm{III})$ complex and amino acids. A plausible mechanism was proposed form the kinetics study. And the rate equations derived from mechanism can explain all experimental phenomena. The activation parameters along with the second order rate constants were calculated.
\end{abstract}

Keywords: Bis(dihydrogen tellurate)argentate(III), amino acid, Kinetics and mechanism, Redox reactions

\section{INTRODUCTION}

Transition metals in a higher oxidation state can be stabilized by chelation with suitable polydentate ligands, such as diperiodatargentate(III) ${ }^{[1]}$ [ethylenebis(biguan- ide) silver(III)]..[. ${ }^{[2]}$ These complexes exist in a suitable aqueous solution. $\mathrm{Ag}(\mathrm{III})$ complexes were stabilized in alkaline medium by periodate or tellurate ions. ${ }^{[3]}$ These complexes, $\mathrm{Ag}(\mathrm{III}), \mathrm{Cu}(\mathrm{III}), \mathrm{Ni}(\mathrm{IV})$, can be used as an oxidation reagents in organic chemistry and analytical chemistry. ${ }^{[4,5]}$ As oxidation reagents, these complexes have been extensively studied.

Amino acid act not only as the building blocks in biological molecules, ${ }^{[6]}$ but they also play a significant role in metabolism, and play key roles in many neuro-chemical response mechanisms, such as memory, appetite control and pain transmission..$^{[7,8]}$ Amino acids can undergo many types of reaction depending on whether a particular amino acid contains non-polar groups or polar substituents. The oxidation of amino acids is of interest as the oxidation products differ for different oxidants, these oxidation reactions display diverse reaction mechanisms, oxidative deamination and decarboxylation decarboxylation..$^{[9-19]}$ Thus, the study of amino acids becomes important because of their biological significance and selectivity towards the oxidant.

\section{EXPERIMENTAL SECTION}

\section{Regents}

All the reagents used were of A.R. grade. All solutions were prepared with doubly distilled water. Amino acid was changed to Potassium salt by adding $\mathrm{KOH}$ solution, molar ratio of amino acid and $\mathrm{KOH}$ is $1: 2$. Solution of bis(dihydrogen tellurate)argentate(III) ion was standardized by the method reported earlier ${ }^{[3]}$ Its UV spectrum has a characteristic absorption band at 350 $\mathrm{nm}$, which was found to be consistent with the reported. The concentration of bis(dihydrogen tellurate)argentate(III) was derived by its absorption at $\lambda=350$ $\mathrm{nm}$. Solution of bis(dihydrogen tellurate)argentate(III) was always freshly prepared before use with doubly-distilled water. The ionic strength I was maintained by adding $\mathrm{KNO}_{3}$ solution and the $\mathrm{pH}$ value of the reaction mixture was regulated with $\mathrm{KOH}$ solution.

Synthesis of bis(dihydrogen telluarte)argentate(III)

$\mathrm{AgNO}_{3}(2.72 \mathrm{~g}), \mathrm{H}_{6} \mathrm{TeO}_{6}(7.34 \mathrm{~g}), \mathrm{K}_{2} \mathrm{~S}_{2} \mathrm{O}_{8}(13 \mathrm{~g})$ and $\mathrm{KOH}(18 \mathrm{~g})$ were taken in a $500 \mathrm{ml}$ round bottomed flask. $150 \mathrm{ml}$ of demineralised water were added. The mixture was heated to boiling while stirring. After 10 minutes of boiling an orangish-yellow froth was obtained and the mixture was heated for another 10 minutes. The mixture was left to cool to room temperature and filtered through a Gooch crucible. The solution was cooled in an ice bath to eliminate as much of potassium sulphate as possible and the solution filtered again while cold. The resulting orangish-red clear filtrate was left to attain room temperature. In order to isolate the complex, $80 \mathrm{ml}$ of $\mathrm{NaNO}_{3}$ saturated solution were added to the solution and the mixture left to crystallise. Almost immediately crystals started appearing and crystallisation is complete when the supernatant liquid is colourless. The crystals were filtered and washed several times with demineralised water until the complex itself starts dissolving, which is indicated by the orange-red drops being formed under the crucible. In this way one can be sure of eliminating sodium and potassium hydroxide since this complex is insoluble in concentrated hydroxide solution and the $\mathrm{Ag}$ (III) complex, $\mathrm{Na}_{5}\left[\mathrm{Ag}\left(\mathrm{H}_{2} \mathrm{TO}_{6}\right)_{2}\right]$, was obtained.

\section{Apparatus and Kinetics Measurements}

Since the reaction rate was too fast to be monitored by the usual methods, kinetic measurements were performed on a rapid kinetic technique (stoppedflow SX20, Applied Photophysics Limited, United Kingdom ), attached with a circulating water from a thermostat (BG-chiller E10, Baijing Biotech Inc., Beijing).

All reactions were monitored under pseudo-first order conditions, with at least a ten-fold excess of amino acids. The reactions were started by the mixing of equal volumes $(128 \mu \mathrm{l})$ of a solution of the $\mathrm{Ag}(\mathrm{III})$ complex with a solution of the amino acid directly in the stopped-flow instrument. The reaction of the amino acid with the $\mathrm{Ag}(\mathrm{III})$ complex was monitored as a decrease of absorbance at the maximum absorbance at $350 \mathrm{~nm}$. Observed rate constants were calculated by a fit of a single exponential function to the kinetic traces. Reported pseudo-first-order rate constants, $k_{\mathrm{obs}}$, are mean values of at least five independent kinetic runs, using a standard least-squares minimizing routine.

Product Analysis

Solution having known concentrations of $[\mathrm{Ag}(\mathrm{III})],\left[\mathrm{OH}^{-}\right]$and $\left[\mathrm{H}_{4} \mathrm{TeO}_{6}{ }_{6}^{2-}\right]$ were mixed with an excess of amino acid. The completion of the reaction was marked by the complete disapearance of the $\mathrm{Ag}(\mathrm{III})$ color. ${ }^{[20]}$ After completion of the reaction, the main reaction products were identified as aldehydes by a spot test, ${ }^{[21]}$ and ammonia by Nessler's reagent.

Free radical trapping experiment

Under the reaction conditions used for kinetic measurements, a $50 \mathrm{~mL}$ solution of amino acid containing $10 \%$ acrylonitrile was mixed with a $25 \mathrm{~mL}$ $\mathrm{Ag}$ (III) solution in a 3-neck flask; both solutions were bubled for 30 min with nitrogen gas before mixing. By stirring the reaction mixture for $4 \mathrm{~h}$ under the protection of nitrogen gas, no precipitates of polyacrylonitrile could be noticed. This observation implies that involvement of free radicals in the reaction course is imrobable.

\section{RESULTS AND DISCUSSION}

\section{Protolytic equilibria}

Under the reaction conditions used in the present work, i.e., $0.02 \mathrm{~mol} / \mathrm{L}<$ $\left[\mathrm{OH}^{-}\right]<0.11 \mathrm{~mol} / \mathrm{L}$, we ensure that $\left[\mathrm{OH}^{-}\right]$remains constant during the reaction course. Protolysis constants of amino acids have been reported to be: $\mathrm{pKa}$ $(\alpha-\mathrm{COOH})=2.33$, and $\mathrm{pKa}\left(-\mathrm{NH}_{3}^{+}\right)=9.74$ for leucine, $\mathrm{pKa}(\alpha-\mathrm{COOH})=2.32$, and $\mathrm{pKa}\left(-\mathrm{NH}_{3}{ }^{+}\right)=9.76$ for isoleucine, $\mathrm{pKa}(\alpha-\mathrm{COOH})=2.29$, and $\mathrm{pKa}\left(-\mathrm{NH}_{3}^{+}\right)=9.72$ for valine. ${ }^{[22]}$ It can be calculatedon the basis of the equilibrium constants that the amino acids are in the anionic form $\mathrm{RCH}_{2}\left(\mathrm{H}_{2} \mathrm{~N}\right) \mathrm{COO}^{-}$in the alkaline medium we used. Several protolytic equilibria of the tellurate in aqueous media have been describedin the literature. ${ }^{[23]}$ The following two equilibria, together with equilibrium constants, were reported for potassium tellurate dissolved in aqueous alkaline medium.

$$
\begin{array}{lrr}
\mathrm{H}_{5} \mathrm{TeO}_{6}^{-}+\mathrm{OH}^{-} & \mathrm{H}_{4} \mathrm{TeO}_{6}{ }^{2-}+\mathrm{H}_{2} \mathrm{O} & \operatorname{lg~Ka}=3.049 \\
\mathrm{H}_{3} \mathrm{TeO}_{6}{ }^{3-}+\mathrm{H}_{2} \mathrm{O}^{\mathrm{Ka} a_{1}}= & \mathrm{H}_{4} \mathrm{TeO}_{6}{ }^{2-}+\mathrm{OH}^{-} & \operatorname{lg~\mathrm {Ka}_{2}}=1.00
\end{array}
$$

Based on the $K_{\mathrm{a} 2}$ zquilibrium constants, if $\left[\mathrm{OH}^{-}\right]=0.01 \mathrm{~mol} \cdot \mathrm{L}^{-1}$ $\left.\left[\mathrm{H}_{4} \mathrm{TeO}_{6}{ }^{2-}\right]:\left[\mathrm{H}_{5} \mathrm{TeO}_{6}^{-}\right] \overline{\mathrm{H}}_{3} \mathrm{IeU}_{6}{ }^{3-}\right]=1000: 89: 1$. Hence in the concentration range of $\mathrm{OH}^{-}$used in this work, the $\mathrm{H}_{5} \mathrm{TeO}_{6}^{-}$and $\mathrm{H}_{3} \mathrm{TeO}_{6}^{3-}$ can be neglected. The 
calculations reveal that under our experimental conditions $\mathrm{H}_{4} \mathrm{TeO}_{6}{ }^{2-}$ is the predominant species whereas the $\mathrm{H}_{3} \mathrm{TeO}_{6}{ }^{3-}$ and $\mathrm{H}_{5} \mathrm{TeO}_{6}^{-}$make a very minor contribution to the total tellurate speciation.

Influence of $\left[\mathrm{OH}^{-}\right]$and $\left[\mathrm{H}_{4} \mathrm{TeO}_{6}^{2-}\right]$ on the reaction rates

At fixed concentration of $[\mathrm{Ag}(\mathrm{III})]\left[\mathrm{OH}^{-}\right]$[amino acid] ionic strength $\mathrm{I}$ and temperature, the value of $k_{\text {obs }}$ decreased with the increase concentration of $\mathrm{H}_{4} \mathrm{TeO}{ }_{6}^{2-}$. The plot of $1 / k_{\text {obs }}$ versus $\left[\mathrm{H}_{4} \mathrm{TeO}_{6}^{2-}\right]$ was straight line with a positive intercept (Table1). shows that tellurate is the product of the pre- equilibrium. The equation (3) can be expressed as:

$\left[\mathrm{Ag}\left(\mathrm{H}_{2} \mathrm{TeO}_{6}\right)_{2}\right]^{5-}+2 \mathrm{H}_{2} \mathrm{O} \underset{K_{1}}{\rightleftharpoons}\left[\mathrm{Ag}(\mathrm{OH})\left(\mathrm{H}_{2} \mathrm{O}\right)\left(\mathrm{H}_{2} \mathrm{TeO}_{6}\right)\right]^{2-}+\mathrm{H}_{3} \mathrm{TeO}_{6}{ }^{3-}$

The second order rate constant, $k^{\prime}$, was calculated, and $1 / k^{\prime}$ versus $\left[\mathrm{H}_{4} \mathrm{TeO}_{6}{ }^{2-}\right]$ was also a straight line (Figure 1 , Figure 2 and Figure 3 ).

At fixed concentration of $[\mathrm{Ag}(\mathrm{III})]\left[\mathrm{H}_{4} \mathrm{TeO}_{6}^{2-}\right.$ [ [amino acid] ionic strength I and temperature, the value of $k_{\mathrm{obs}}$ decreased with the increase of the [OH']. The plot of $1 / k_{\mathrm{obs}}$ versus $\left[\mathrm{OH}^{-}\right]$was a straight line (Table 2), and the influence of $\left[\mathrm{OH}^{-}\right]$on the reaction rates comes from the form of tellurate species in the aqueous alkaline medium. The second order rate constants were calculated and $1 / k^{\prime}$ versus $\left[\mathrm{OH}^{-}\right]$was also a straight line (Figure 4, Figure 5 and Figure 6 ). The value of $k_{\text {obs }}$ increased on addition of $\mathrm{KNO}_{3}$ solution (Table3)

Table 1. $k_{\mathrm{obs}} / \mathrm{s}^{-1}$ varying with different $\left[\mathrm{H}_{4} \mathrm{TeO}_{6}^{2-}\right]$ at $298.2 .2 \mathrm{~K}$.

\begin{tabular}{|c|c|c|c|c|c|c|c|}
\hline \multicolumn{2}{|c|}{$\mathrm{C} /(\mathrm{mol} / \mathrm{L})$} & 0.001 & 0.002 & 0.003 & 0.004 & 0.005 & 0.006 \\
\hline \multirow{2}{*}{ leucine } & $10^{2} k^{\text {obs }}$ & 8.762 & 8.348 & 8.037 & 7.778 & 7.460 & 7.247 \\
& $k^{\circ}$ & 2.503 & 2.385 & 2.296 & 2.222 & 2.131 & 2.071 \\
\multirow{4}{*}{ isoleucine } & $10^{2} k$ obs & 9.891 & 9.345 & 8.971 & 8.495 & 8.135 & 7.785 \\
& $k^{\circ}$ & 2.826 & 2.670 & 2.563 & 2.427 & 2.324 & 2.224 \\
\multirow{2}{*}{ valine } & $10^{2} k_{\text {obs }}$ & 9.292 & 8.921 & 8.596 & 8.235 & 7.945 & 7.711 \\
& $k^{\circ}$ & 2.655 & 2.549 & 2.456 & 2.353 & 2.27. & 2.203 \\
\hline
\end{tabular}

$[\mathrm{Ag}(\mathrm{III})]=1.651 \times 10^{-4} \mathrm{~mol} / \mathrm{L},[\mathrm{OH}-]=2.00 \times 10^{-2} \mathrm{~mol} / \mathrm{L},[$ amino $\mathrm{acid}]=3.50 \times 10^{-2} \mathrm{~mol} / \mathrm{L}, \mathrm{I}=0.20 \mathrm{~mol} / \mathrm{L}, \mathrm{T}=298.2 \mathrm{~K}$

Table 2. $k_{\mathrm{obs}} / \mathrm{s}^{-1}$ varying with different $\left[\mathrm{OH}^{-}\right]$at $298.2 \mathrm{~K}$.

\begin{tabular}{|l|l|l|l|l|l|l|l|l|l|l|l|}
\hline \multicolumn{2}{|l|}{$\mathrm{C} /(\mathrm{mol} / \mathrm{L})$} & 0.02 & 0.03 & 0.04 & 0.05 & 0.06 & 0.07 & 0.08 & 0.09 & 0.10 & 0.11 \\
\hline \multirow{2}{*}{ leucine } & $10^{2} k_{\text {obs }}$ & 8.102 & 5.997 & 5.185 & 4.290 & 3.731 & 3.493 & 3.119 & 2.877 & 2.682 & 2.451 \\
& $10 k^{\circ}$ & 23.15 & 17.13 & 14.81 & 12.26 & 10.66 & 9.980 & 8.911 & 8.220 & 7.663 & 7.003 \\
isoleucine & $10^{2} k_{\text {obs }}$ & 9.441 & 7.577 & 6.415 & 5.436 & 4.744 & 4.081 & 3.645 & 3.412 & 3.086 & 2.750 \\
& $10 k^{\circ}$ & 26.97 & 21.65 & 18.33 & 15.53 & 13.55 & 11.66 & 10.41 & 9.749 & 8.817 & 7.857 \\
valine & $10^{2} k^{\text {obs }}$ & 8.225 & 6.548 & 5.557 & 4.737 & 4.209 & 3.826 & 3.520 & 3.217 & 3.030 & 2.812 \\
& $10 k^{\circ}$ & 23.50 & 18.71 & 15.91 & 13.53 & 12.03 & 10.93 & 10.06 & 9.191 & 8.657 & 8.034 \\
\hline
\end{tabular}

$[\mathrm{Ag}(\mathrm{III})]=1.651 \times 10^{-4} \mathrm{~mol} / \mathrm{L},\left[\mathrm{H}_{4} \mathrm{TeO}_{6}{ }^{2-}\right]=3.00 \times 10^{-3} \mathrm{~mol} / \mathrm{L},[\mathrm{amino}$ acid $]=3.50 \times 10^{-2} \mathrm{~mol} / \mathrm{L}, \mathrm{I}=0.23 \mathrm{~mol} / \mathrm{L}, \mathrm{T}=298.2 \mathrm{~K}$.

Tabel 3. $\mathrm{k}_{\mathrm{obs}} / \mathrm{s}^{-1}$ varying with different ion strength at $298.2 \mathrm{~K}$.

\begin{tabular}{|c|l|c|c|c|c|c|}
\hline \multicolumn{2}{|c|}{$\mathrm{I} /(\mathrm{mol} / \mathrm{L})$} & 0.08 & 0.18 & 0.28 & 0.38 & 0.48 \\
\hline \multirow{3}{*}{$10^{2} k_{\text {obs }}$} & leucine & 7.312 & 8.185 & 8.087 & 8.113 & 7.973 \\
& isoleucine & 8.732 & 10.07 & 10.15 & 9.506 & 9.617 \\
& valine & 7.977 & 8.965 & 9.075 & 8.827 & 8.798 \\
\hline
\end{tabular}

$[\mathrm{Ag}(\mathrm{III})]=1.651 \times 10^{-4} \mathrm{~mol} / \mathrm{L},\left[\mathrm{OH}^{-}\right]=2.00 \times 10^{-2} \mathrm{~mol} / \mathrm{L},\left[\mathrm{H}_{4} \mathrm{TeO}_{6}{ }^{2-}\right]=3.00 \times 10^{-3} \mathrm{~mol} / \mathrm{L},[\mathrm{amino}$ acid $]=3.50 \times 10^{-2} \mathrm{~mol} / \mathrm{L}, \mathrm{T}=298.2 \mathrm{~K}$ 


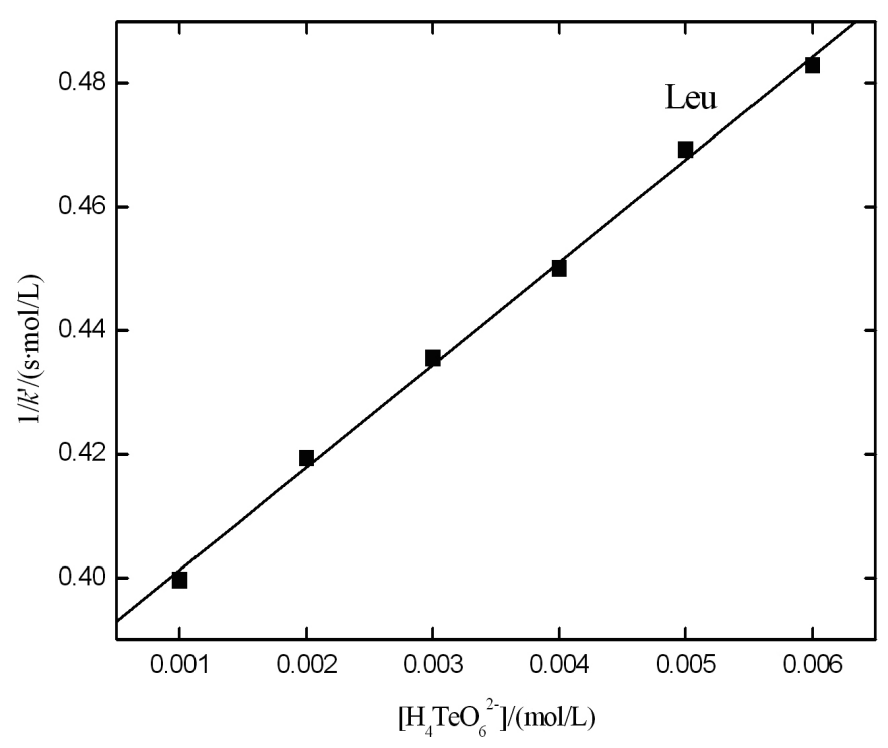

Figure 1: a plot of $1 / \mathrm{k}$ versus $\left[\mathrm{H}_{4} \mathrm{TeO}_{6}{ }^{2-}\right]$ for the oxidation of leucine by $\mathrm{Ag}(\mathrm{III})$ complex at $298.2 \mathrm{~K}$.

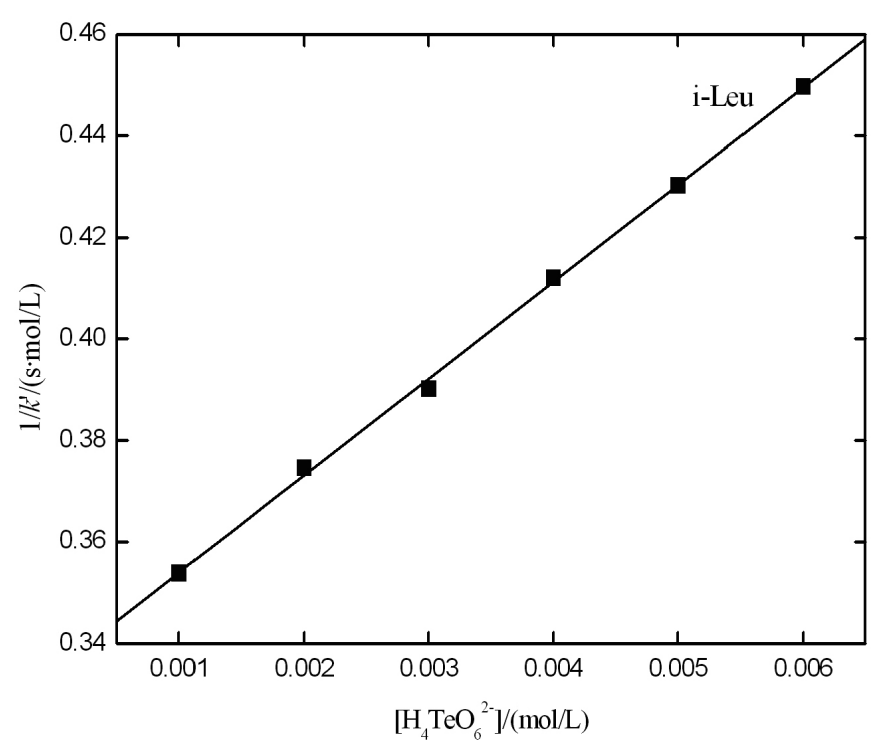

Figure 2: a plot of $1 / \mathrm{k}^{\prime}$ versus $\left[\mathrm{H}_{4} \mathrm{TeO}_{6}{ }^{2-}\right]$ for the oxidation of isoleucine by $\mathrm{Ag}(\mathrm{III})$ complex at $298.2 \mathrm{~K}$.

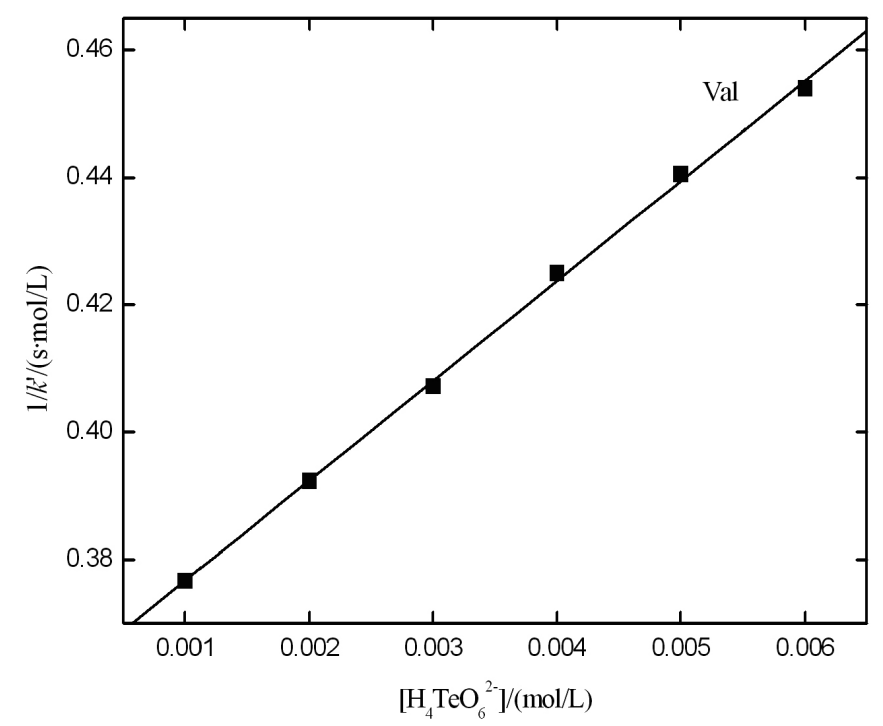

Figure 3: a plot of $1 / \mathrm{k}^{\prime}$ versus $\left[\mathrm{H}_{4} \mathrm{TeO}_{6}{ }^{2-}\right]$ for the oxidation of valine by $\mathrm{Ag}(\mathrm{III})$ complex at $298.2 \mathrm{~K}$

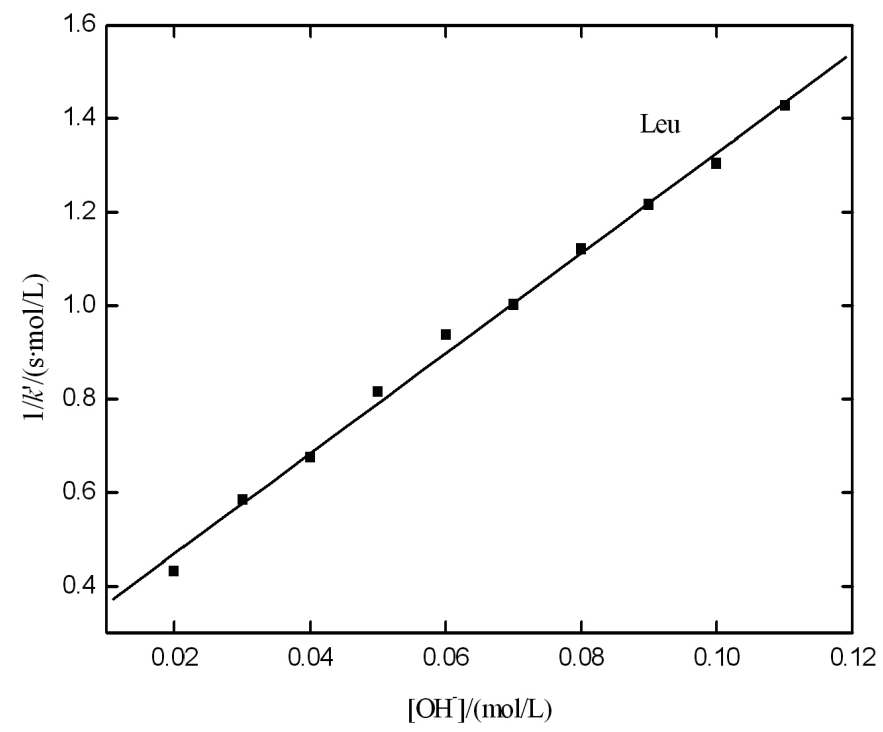

Figure 4: a plot of $1 / \mathrm{k}^{\text {v versus }}\left[\mathrm{OH}^{-}\right]$for the oxidation of leucine by $\mathrm{Ag}(\mathrm{III})$ complex at $298.2 \mathrm{~K}$. 


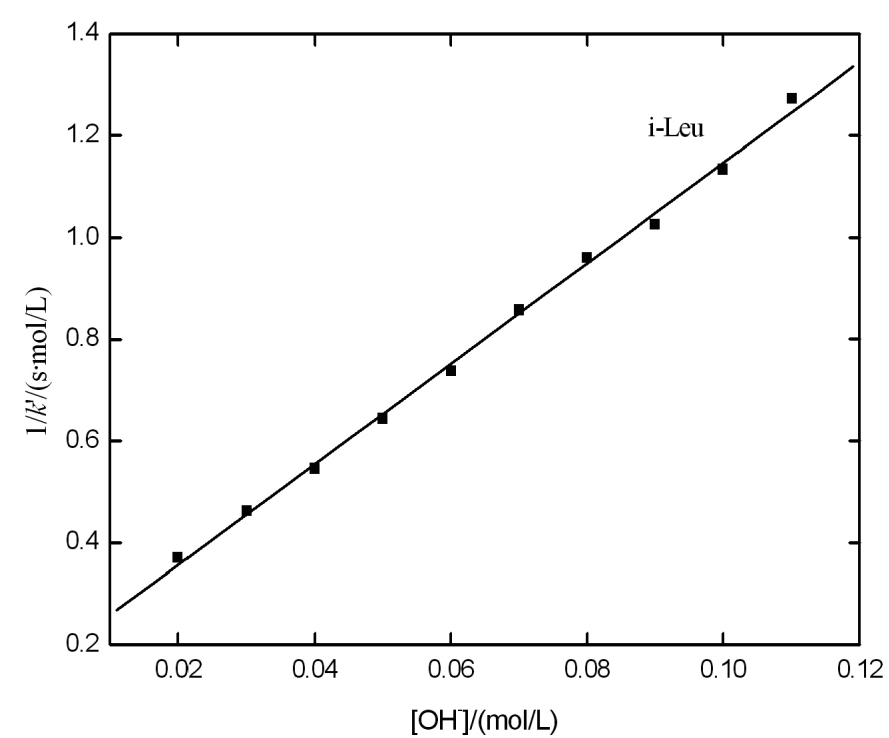

Figure 5: a plot of $1 / \mathrm{k}^{\prime}$ versus $\left[\mathrm{OH}^{-}\right]$for the oxidation of isoleucine by $\mathrm{Ag}(\mathrm{III})$ complex at $298.2 \mathrm{~K}$.

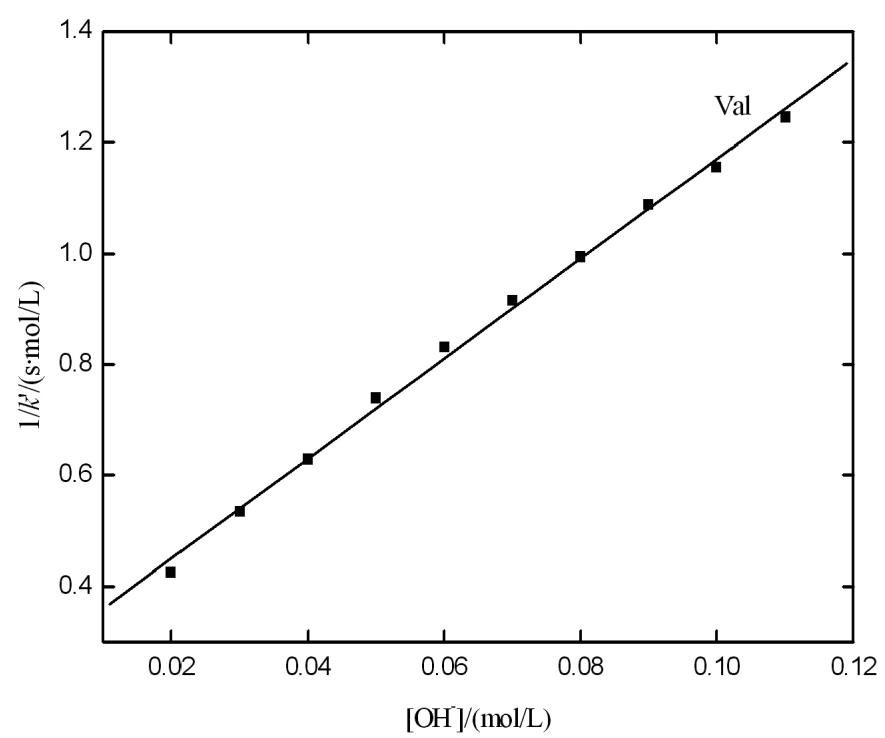

Figure 6: a plot of $1 / \mathrm{k}^{\prime}$ versus $\left[\mathrm{OH}^{-}\right]$for the oxidation of valine by $\mathrm{Ag}(\mathrm{III})$ complex at $298.2 \mathrm{~K}$.

Table 4. $k_{\mathrm{obs}} / \mathrm{s}^{-1}$ varying with different [amino acid] at different temperatures

\begin{tabular}{|c|c|c|c|c|c|c|c|c|}
\hline \multicolumn{2}{|l|}{$\mathrm{C} /(\mathrm{mol} / \mathrm{L})$} & 0.02 & 0.04 & 0.06 & 0.08 & 0.10 & \multirow[t]{2}{*}{$\mathrm{n}_{\mathrm{ap}}$} & \multirow[t]{2}{*}{$\mathrm{R}$} \\
\hline Amino acid & $\mathrm{T} /(\mathrm{K})$ & & & $10^{2} k_{\text {obs }}$ & & & & \\
\hline \multirow{5}{*}{ leucine } & 293.2 & 3.094 & 6.278 & 9.095 & 12.17 & 15.87 & 1.00 & 0.999 \\
\hline & 298.2 & 4.566 & 9.001 & 13.64 & 18.07 & 22.66 & 1.00 & 0.999 \\
\hline & 303.2 & 7.019 & 14.23 & 21.34 & 28.03 & 35.51 & 1.00 & 0.999 \\
\hline & 308.2 & 10.21 & 20.55 & 30.77 & 40.80 & 51.32 & 1.00 & 0.999 \\
\hline & 313.2 & 15.85 & 31.76 & 47.95 & 63.97 & 79.90 & 1.00 & 0.999 \\
\hline \multirow{5}{*}{ isoleucine } & 293.2 & 3.224 & 6.471 & 9.792 & 13.19 & 16.26 & 1.00 & 0.999 \\
\hline & 298.2 & 5.245 & 10.48 & 15.66 & 21.01 & 26.06 & 1.00 & 0.999 \\
\hline & 303.2 & 8.191 & 16.34 & 24.41 & 32.60 & 40.82 & 1.00 & 0.999 \\
\hline & 308.2 & 11.53 & 23.03 & 34.56 & 46.21 & 57.72 & 1.00 & 0.999 \\
\hline & 313.2 & 18.26 & 36.56 & 54.61 & 73.05 & 91.32 & 1.00 & 0.999 \\
\hline \multirow{5}{*}{ valine } & 293.2 & 3.116 & 6.356 & 9.542 & 12.61 & 15.99 & 1.01 & 0.999 \\
\hline & 298.2 & 5.026 & 10.25 & 15.28 & 20.44 & 25.25 & 1.00 & 0.999 \\
\hline & 303.2 & 7.881 & 15.71 & 23.61 & 31.33 & 39.13 & 1.00 & 0.999 \\
\hline & 308.2 & 11.05 & 22.21 & 33.23 & 44.46 & 55.25 & 1.00 & 0.999 \\
\hline & 313.2 & 19.18 & 38.35 & 57.11 & 76.53 & 95.65 & 0.97 & 0.998 \\
\hline
\end{tabular}

$[\mathrm{Ag}(\mathrm{III})]=1.651 \times 10^{-4} \mathrm{~mol} / \mathrm{L},[\mathrm{OH}]=2.00 \times 10^{-2} \mathrm{~mol} / \mathrm{L},\left[\mathrm{H}_{4} \mathrm{TeO}_{6}^{2-}\right]=3.00 \times 10^{-3} \mathrm{~mol} / \mathrm{L},[$ amino acid $]=3.50 \times 10^{-2} \mathrm{~mol} / \mathrm{L}, \mathrm{I}=0.33 \mathrm{~mol} / \mathrm{L}, \mathrm{n}_{\text {ap }}$ is the apparent reaction order, which are the slops of the plot of $\ln k_{\mathrm{obs}}$ versus $\ln$ [amino acid] at different temperature, and $\mathrm{R}$ is the relative coefficient 
Influence of [amino acid] on the reaction rates

At fixed concentration of $[\mathrm{Ag}(\mathrm{III})]\left[\mathrm{OH}^{-}\right]\left[\mathrm{H}_{4} \mathrm{TeO}_{6}{ }^{2-}\right]$ ionic strength I. The values of $k_{\mathrm{obs}}$ were determined at different temperature and amino acid concentrations. The $k_{\text {obs }}$ values were found to increase with increase concentration of amino acid at all temperatures, the order with respect to amino acid is unity, which were the slopes of the plots of $\ln k$ versus $\ln$ [amino acid], and plots of $k_{\text {obs }}$ versus [amino acid] were straight lines through the origin at different temperature (Tabel 4), from which it can be known that a molecular of amino acid participated in the rate controlled step, Equation (4) can be obtained as below:

$\left[\mathrm{Ag}(\mathrm{OH})\left(\mathrm{H}_{2} \mathrm{O}\right)\left(\mathrm{H}_{2} \mathrm{TeO}_{6}\right)\right]^{2-}+\mathrm{RCH}_{2}\left(\mathrm{NH}_{2}\right) \mathrm{COO}^{-}$intermediate $+\mathrm{H}_{2} \mathrm{O}(4)$

\section{Reaction Mechanism} below:

According to the kinetics, the reaction mechanism can be expressed as So the equation can be obtained:
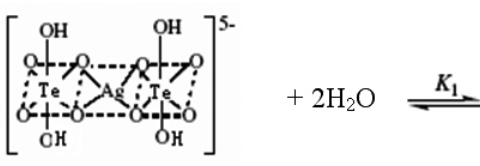

A

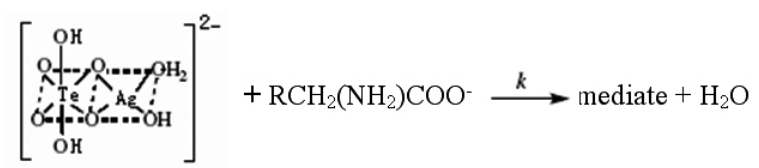

intermediate fast $\mathrm{RCHOCOO}^{-}+\mathrm{NH}_{3}+\mathrm{H}_{4} \mathrm{TeO}_{6}^{2-}+\mathrm{OH}^{-}$

$$
[\mathrm{Ag}(\mathrm{III})]_{\mathrm{Tot}}=[\mathrm{A}]_{\mathrm{e}}+[\mathrm{B}]_{\mathrm{e}}
$$

where "e" means equilibrium concentration of the kinds of $\operatorname{Ag}(\mathrm{III})$ species.

$\mathrm{r}=-\mathrm{d}[\mathrm{Ag}(\mathrm{III})]_{\text {Tot }} / \mathrm{dt}=k_{\mathrm{obs}}[\mathrm{Ag}(\mathrm{III})]_{\text {Tot }}$

$=k \cdot[\mathrm{B}]_{\mathrm{e}} \cdot[$ amino acid $]=k^{\prime}[\mathrm{Ag}(\mathrm{III})]_{\mathrm{Tot}} \cdot[$ amino acid $]$

Where $k$ is the second order rate constant.

Then $k_{\mathrm{obs}}$ can be expressed as:

$$
k_{c o s}=\frac{\left.k \mathrm{~K}_{1} \mathrm{~K}_{22} \text { [arino acid }\right]}{\left[\mathrm{H}_{4} \mathrm{TeO}_{6}{ }^{2}\right][\mathrm{OH}]+\mathrm{K}_{1} \mathrm{~K}_{22}}=k \text { [amino acid] }
$$

Where,

$$
k=\frac{k \mathrm{~K}_{1} \mathrm{~K}_{22}}{\left[\mathrm{H}_{4} \mathrm{TeO}_{6}{ }^{2-}\right]\left[\mathrm{OH}^{-}\right]+\mathrm{K}_{1} \mathrm{~K}_{\mathrm{2} 2}}
$$

Equation (13),(14) can also be obtained:

$$
\begin{gathered}
\frac{1}{k_{\mathrm{obs}}}=\frac{1}{k[\text { amino acid }]}+\frac{\left[\mathrm{H}_{4} \mathrm{TeO}_{6}{ }^{2 \cdot}\right]\left[\mathrm{OH}^{-}\right]}{k K_{1} K_{a 2}} \\
\frac{1}{k}=\frac{1}{k}+\frac{\left[\mathrm{H}_{4} \mathrm{TeO}_{6}{ }^{2}\right]\left[\mathrm{OH}^{-}\right]}{\mathrm{K}_{1} \mathrm{~K}_{\mathrm{a} 2}}
\end{gathered}
$$

From the equation presented above, it is demonstrated that a plot of $k_{\text {obs }}$ versus [amino acid] is a straight line, which through the origin. The plots of $1 / k_{\text {obs }}$ versus $\left[\mathrm{OH}^{-}\right]$and $\left[\mathrm{H}_{4} \mathrm{TeO}_{6}{ }^{2-}\right]$ are all straight line. The plots of $1 / k^{\prime}$ versus $\left[\mathrm{OH}^{-}\right]$and $\left[\mathrm{H}_{4} \mathrm{TeO}_{6}{ }^{2-}\right]$ are all straight line too. So the rate law obtained from reaction mechanism can explain all these experimental phenomena. The activation parameters were obtained by a fit of the natural logarithm of rate constant of the rate determining step, $\ln \left(k^{\prime}\right)$ versus $1 / \mathrm{T}$ to the Arrhenius equation (Table 5).

\section{CONCLUSION}

In this study, the oxidation of leucine, isoleucine and valine by bis(dihydrogen tellurate)argentate(III) was investigated using the stoppedflow technique. The rate law for the proposed reaction mechanism explains all the experimental observations. The reactions products in basic medium are aldehydes. The results support the notion that the $\mathrm{Ag}(\mathrm{III})$ complex can be used as a reagent for a transformation of peptides and proteins in alkaline medium. Studies are in progress toward this direction. And the reaction is similar to the

\begin{tabular}{|c|c|c|c|}
\hline amino acid & $T / \mathrm{K}$ & $k^{\prime} /\left(\mathrm{mol}^{-1} \cdot \mathrm{L} \cdot \mathrm{s}^{-1}\right)$ & activation parameters \\
\hline \multirow[t]{2}{*}{ Leucine } & $\begin{array}{r}293.2 \\
298.2 \\
303.2 \\
308.2\end{array}$ & $\begin{array}{l}1.548 \\
2.266 \\
3.536 \\
5.121\end{array}$ & \multirow{2}{*}{$\begin{array}{l}E \mathrm{a}=62.47 \pm 1.43 \mathrm{KJ} / \mathrm{mol} \\
\mathrm{H}^{\neq}=59.99 \pm 1.43 \mathrm{KJ} / \mathrm{mol} \\
\mathrm{S}^{\neq}=-36.82 \pm 4.74 \mathrm{~J} /(\mathrm{mol} \cdot \mathrm{K}) \\
k=3.268 \pm 0.663 \mathrm{~L} /(\mathrm{mol} \cdot \mathrm{s}) \\
\mathrm{K}_{1}=(1.988 \pm 1.696) \times 10^{-5} \mathrm{~mol} / \mathrm{L}\end{array}$} \\
\hline & 313.2 & 7.969 & \\
\hline \multirow[t]{2}{*}{ isoleucine } & $\begin{array}{r}293.2 \\
298.2 \\
303.2 \\
308.2\end{array}$ & $\begin{array}{l}\frac{1.627}{2.617} \\
\frac{4.081}{5.766}\end{array}$ & \multirow{2}{*}{$\begin{array}{l}E \mathrm{a}=64.74 \pm 1.59 \mathrm{KJ} / \mathrm{mol} \\
\mathrm{H}^{\neq}=62.26 \pm 1.59 \mathrm{KJ} / \mathrm{mol} \\
\mathrm{S}^{\neq}=-28.25 \pm 5.24 \mathrm{~J} /(\mathrm{mol} \cdot \mathrm{K}) \\
k=4.634 \pm 1.648 \mathrm{~L} /(\mathrm{mol} \cdot \mathrm{s}) \\
\mathrm{K}_{1}=(1.536 \pm 0.881) \times 10^{-5} \mathrm{~mol} / \mathrm{L}\end{array}$} \\
\hline & 313.2 & 9.126 & \\
\hline \multirow[t]{2}{*}{ valine } & $\begin{array}{l}\frac{293.2}{298.2} \\
\frac{303.2}{308.2} \\
308.2\end{array}$ & $\begin{array}{l}\frac{1.583}{2.540} \\
\frac{3.926}{5.540}\end{array}$ & \multirow{2}{*}{$\begin{array}{l}E \mathrm{a}=66.82 \pm 2.66 \mathrm{KJ} / \mathrm{mol} \\
\mathrm{H}^{\neq}=64.34 \pm 2.66 \mathrm{KJ} / \mathrm{mol} \\
\mathrm{S}^{\neq}=-21.52 \pm 8.81 \mathrm{~J} /(\mathrm{mol} \cdot \mathrm{K}) \\
k=3.234 \pm 0.464 \mathrm{~L} /(\mathrm{mol} \cdot \mathrm{s}) \\
\mathrm{K}_{1}=(2.458 \pm 1.458) \times 10^{-5} \mathrm{~mol} / \mathrm{L}\end{array}$} \\
\hline & 313.2 & 9.565 & \\
\hline
\end{tabular}
metabolizability of the amino acid in the human body. So we can learn more about the reaction of amino acid in the body.

Table 5: the second order rate constants at different temperature and activation parameters of these reactions at $298 \mathrm{~K}$.

\section{REFERENCES}

(1). a) J. H. Shan, S.Y. Huo, S. G. Shen, H. W. Sun, A. Z. Wang, Chem. J. Chinses Univer., 26, 706,(2005). b) P. Jaya Parkash Rao, B. Sethuram, T. N, Rao, React. Kinet, Catal. Lett, 29, 289 , (1985). c) J. H. Shan, S. M. Li, S. Y. Huo, S. G. Shen, H. W. Sun, Chineses J. Chem. 24, 478, (2006). d) J. H. Shan, S. M. Li, S. Y. Huo, S. G. Shen, W. J. Zhao, H. W. Sun, J. Chem. Research(s), 7, 424, (2006).

(2). a) P. Bandyopdhyay, S. Mukhopadhyay, Polyhedron. 21, 1893, (2002). b) A. Das, S. Mukhopadhyay, Polyhedron. 23, 895, (2004).

(3). a) A. Balikungeri, M. Pelletier, D. Minnier. Inorganica Chemica Acta., 22, 7, (1977). b) L. J. Kirschenbaum, J. H. Ambrus, G.. Atkinson, Inorg. Chem., 12, 2832, (1973).

(4). K. K. S. Gupta, B. K. Nandy, S. S. Gupta, J. Org. Chem., 59, 858, (1994).

(5). a). S. Chandra, K. L. Yadava, Talanta, 15, 349, (1968). b). P K Jaiswal, K L Yadava, Talanta, 17, 236, (1970).

(6). S. Mho, D.C. Johnson, J. Electroanal. Chem., 495, 152, (2001).

(7). H. Shen, S. R. Witowski, B. W. Boyd, R.T. Kennedy, Anal. Chem., 71 987, (1999).

(8). T. Hokfelt, Neuron, 7, 867, (1991).

(9). R. Pascual, M. A. Herraez, Can. J. Chem., 63, 2349, (1985).

(10). R. Pascual, M. A. Herraez, Can. J. Chem., 67, 634, (1989).

(11). B. T. Gowda, P. Jagan, M. Rao, Bull. Chem. Soc. Jpn., 62, 3303, (1989).

(12). Y. R. Katre, A. K. Singh, S. Patil, G.. K. Joshi. Oxidation Communications, 29, 129, (2006).

(13). Y. R. Katre, A. K. Singh, G.. K. Joshi, S.Patil. Oxidation Communications, 29, 137, (2006)

(14). N. Nalwaya; A. Jain; B. L. Hiran, Kinetics and Catalysis, 45, 345, (2004).

(15). R. M. Rodriguez, J. D Andres, E. B. Brillas, J. A. Garrido, J. P. Benito, New J. Chem., 12, 143, (1988)

(16). R. T. Mahesh, M. B. Bellakki, S. T. Nandibewoor. Journal of Chemical Research, 1, 13, (2005).

(17). S. A. Chimatadar, A. K. Kini, S. T. Nandibewoor, Oxidation Communications, 29, 147, (2006).

(18). R. M. Mulla, H. M. Gurubasavaraj, S. T. Nandibewoor., Polish J. Chem., 77, 1833, (2003) 
(19). V. Soni, R. S. Sindal, Raj N.Mehrotra. Polyhedron, 24, 1167, (2005).

(20). T. S. Shi, J. T. He, T. H. Ding, J. Chem. Kin. 23, 815, (1991).

(21). F. Feigl, "Spot Tests in Organic Analysis", Elsevier Publishing Co, New York, 1956. pp.208-236.
(22). Q. Y. Xing, F. F. Pei, R. Q. Xu, J. Pei, Basic Organic Chemistry, Higher Education Press, Beijing, 3th Edit, 2005, P980.

(23). The Teaching and Research Section of Analytical Chemistry in Zhongnan Mining Institute. Handbook of Analytical Chemistry, Beijing: Science publishing Co., 1984, P567. 